\title{
DIFUSÃO DA SULFANILAMIDO-METILPIRIMIDINA PARA O LfQUIDO CEFALORRAQUEANO
}

\author{
Tito Cavallo* \\ Ovidio D. Escalante **
}

A. SPINA-França ***

A difusão de compostos sulfamidicos para o líquido cefalorraqueano (LCR) é variável, dependenđo da taxa existente no sangue e dos caracteres de difusibilidade próprios a cada um dêles ${ }^{2}$. Vários compostos sulfamídicos de ação prolongada têm sido introduzido recentemente na prática; sua capacidade de difusão para o LCR tem-se mostrado variável, não sendo satisfatória em relação a todos ${ }^{5}$. Esta publicação visa apresentar os resultados obtidos com a utilização da 2-sulfanilamido-5-metilpirimidina.

\section{MATERIAL E MÉTODOS}

A concentração de 2-sulfanilamido-5-metilpirimidina (SMP) foi determinada no LCR e no sôro de 30 pacientes portadores de afecções do sistema nervoso, distribuídos em dois grupos.

O primeiro grupo compreende 19 pacientes portadores de afeccōes crônicas do sistema nervoso (SN) não acompanhadas de manifestações evidentes de comprometimento do estado geral. Em todos o LCR era normal quanto à pressão, citologia e concentração protêica total, sendo negativas as reações para globulinas e de fixação do complemento para sifilis e para cisticercose. Dez dos pacientes apresentavam epilepsia (casos 1 a 10); um, hidrocefalia (caso 11); três, neuropatias periféricas (casos 12 a 14); 5 , processos medulares associados a aquilia gástrica (casos 15 a 19), em dois dos quais havia deficiência de absorção de vitamina $B_{12}$, comprovada pelo teste de absorção de radiocianocobalamina (casos 15 e 19).

O segundo grupo compreende 11 pacientes portadores de afecções do sistema nervoso acompanhadas de alterações do LCR. Quatro apresentavam síndrome de Guillain-Barré (casos 20 a 23), caracterizando-se o LCR por apresentar dissociaçāo proteíno-citológica. Nos 7 casos restantes havia acometimento do sistema nervoso central e/ou de seus envoltórios por processos inflamatórios crônicos: um apresentava meningite crônica com surtos de reagudização (caso 24), caracterizando-se o quadro liquórico por pleiocitose (predominantemente a polinucleares neutrófilos) e hiperproteinorraquia; um apresentava neurolues (caso 25), sendo positiva no LCR a reação de Wassermann; 5 apresentavam neurocisticercose, com positividade da reação de fixação do complemento para cisticercose no LCR (casos 26 a 30 ).

Trabalho da Clínica Neurológica da Fac. Med. da Univ. de São Paulo (Prof. Adherbal Tolosa): *Acadêmico estagiário; ** Estagiário bolsista; *** Assistente. 
Todos os pacientes foram submetidos ao mesmo programa quanto a administração da droga: $1 \mathrm{~g}$ de SMP * foi administrada por via oral de início e mais $0,5 \mathrm{~g}$ 12 e 24 horas depois, pela mesma via; 36 horas depois do início da administração de SMP, foi colhido material para estudo. Em cada caso foram colhidas amostras de LCR e de sangue na mesma ocasiāo. A concentração de sulfanilamida foi determinada por uma das variantes do método de Bratton e Marshall 4. Os resultados ( $\mathrm{mg}$ de sulfan:lamida por $1 \mathrm{c0} \mathrm{ml}$ ) foram transformados para o eqüivalente em SMP mediante multiplicação pelo fator de correção (razão entre o pêso molecular da SMP e o da sulfanilamida, eqüivalente a 1,536).

\section{RESULTADOS}

Os resultados obtidos para as concentrações de SMP no LCR e no sangue dos 30 pacientes estudados são apresentados na tabela 1 .

\begin{tabular}{|c|c|c|c|c|c|c|c|c|}
\hline Caso & $L C R$ & Sôro & Caso & $L C R$ & Sôro & Caso & $L C R$ & Sôro \\
\hline 1 & 0,7 & 1,9 & 11 & 0,6 & 5,8 & 21 & 0,7 & 2,4 \\
\hline 2 & 0,6 & 3,1 & 12 & 0,4 & 1,9 & 22 & 2,0 & 3,3 \\
\hline 3 & 0,2 & 2,7 & 13 & 0,6 & 2,9 & 23 & 0,4 & 3,1 \\
\hline 4 & 0,0 & 1,6 & 14 & $\mathrm{C}, 8$ & 3,6 & 24 & 0,6 & 3,7 \\
\hline 5 & $c, 7$ & 2,9 & 15 & 0,5 & 1,6 & 25 & 0,5 & 2,3 \\
\hline 6 & 0,4 & 2,0 & 16 & 0,6 & 2,9 & 26 & 0,4 & 1,9 \\
\hline 7 & 0,4 & 3,0 & 17 & 0,7 & 2,4 & 27 & 1,0 & 5,5 \\
\hline 8 & 0,5 & 2,9 & 18 & 0,9 & 3,4 & 28 & 0,7 & 5,2 \\
\hline 9 & 0,8 & 5,4 & 19 & $\mathrm{C}, 4$ & 1,7 & 29 & 0,4 & 2,9 \\
\hline 10 & 0,5 & 1,8 & 20 & 0,8 & 2,5 & 30 & 0,6 & 2,9 \\
\hline
\end{tabular}

Tabela 1 - Consentração de 2-sulfanilamido-5-metilpirimidina no LCR e no sôro dos 30 pacientes: resultados em $\mathrm{mg}$ por $100 \mathrm{ml}$.

Pacientes com LCR normal - Os resultados encontrados para o LCR e para o sangue dos 19 pacientes com afecçōes do SN não acompanhadas de alterações do LCR são representados pelas estimativas referidas na tabela 2. A correlação entre as concentrações encontradas no LCR e no sangue dêsses casos foi positiva, sendo represcntada pela cifra de 0,51. Este valor de correlação é significativo do ponto de vista estatistico. Em vista disso, foi determinada a relação existente em cada caso entre a concentraçāo de SMP no LCR e no sangue. Os valôres encontrados são representados pela média de $0,2 \mathrm{C} 3 \pm 0,087$.

\footnotetext{
- Palidina Merck.
} 


\begin{tabular}{l|c|c}
\hline Estimativas & LCR & Sôro \\
\hline \hline Média & 0,54 & 2,82 \\
Desvio padrão & 0,21 & 1,17 \\
\hline
\end{tabular}

Tabela 2 Estimativas referentes às concentracōes de 2-sulfanilamido-5-metilpirimidina no LCR e no sôro de 19 pacientes cujo LCR era normal (casos 1 a 19): resultados em $m g$ por $100 \mathrm{ml}$.

Pacientes com LCR alterado - Em todos os pacientes dêste grupo fol verificada a presença de SMP no LCR e a relação entre a conzentração de SMP no LCR e no sangue se achava dentro dos limites de variação estabelecidos pelo estudo do grupo anterior. Faziam exceção apenas dois dos casos de polirradiculoneurite (casos 20 e 22), nos quais os valôres dessa relação foram maiores.

\section{COMENTARIOS}

Após a administração por via oral de compostos sulfamídicos, a concentração máxima no LCR costuma ser observada mais tardiamente que no sangue; assim, para o sulfametoxazol ${ }^{3}$ a concentração máxima é observada, a partir do início da administração, 6 horas depois no sangue e 8 horas depois no LCR. Em vista disso, podem dar resultados enganosos os estudos sôbre a relação entre as taxas no LCR e no sangue em periodos próximos daqueles nos quais as curvas de concentração não apresentam a mesma tendência quanto a aumento ou a diminuição. Para contornar êsse problema foi dada preferência à relação entre as concentrações no LCR e no sangue após o período em que o máximo de concentração é alcançado em ambos. Para a SMP a concentração máxima do sangue costuma ser observada cêrca de 4 horas após a administração por via oral ${ }^{6}$. Assim sendo, em nosso material, as colheitas de LCR e sangue foram feitas cêrca de 12 horas após o inicio da administração, intervalo de tempo suficiente, a nosso ver, para contornar o problema referido.

As dosagens foram feitas após a administração de três doses de SMP, com intervalo de 12 horas entre cada uma; essa norma foi adotada visando estudar o comportamento da droga num periodo correspondente ao tratamento de manutenção.

Os resultados obtidos para os 19 pacientes portadores de afecções do SN de natureza não inflamatória e com LCR normal permitiram verificar que há correlação significativa entre a taxa de SMP no LCR e no sangue. O nível de SMP no LCR corresponde a cêrca da quinta parte daquele que 
é observado no sangue. Esses dados confirmam os resultados referentes ao estudo de 3 casos por Benzing e Dennig ${ }^{1}$.

Entre os 5 pacientes com aquilia gástrica foram registradas duas das concentrações mais baixas de SMP no sangue, respectivamente 1,6 e 1,7 $\mathrm{mg} / 100 \mathrm{ml}$ (casos 15 e 19); apenas nesses dois pacientes havia déficit de absorção da radiocianocobalamina; a relação LCR/sangue quanto ao teor em SMP não se mostrou diferente para êsses pacientes em relação aos demais.

A tendência a aumento da relação $\mathbf{L C R}$ /sangue da concentração de SMP em dois dos casos de polirradiculoneurite foi devida à ocorrência de taxas maiores no LCR. Este fato pode estar na dependência da estase verificada no canal raqueano nessas condições, em virtude da menor reabsorção do LCR, conforme sugerem estudos quanto à composição protêica dêste último na polirradiculoneurite ?

Os dados obtidos para o caso de meningite crônica, para o de neurolues e para os de neurocisticercose mostraram-se dentro dos limites estabelecidos para o grupo de pacientes com LCR normal.

\section{RESUMO E CONCLUSOES}

Foi estudada a relação entre as concentrações de 2-sulfanilamido-5metilpirimidina (SMP) no LCR e no sangue após a administração oral da droga a 30 pacientes. Do total, 19 apresentavam LCR normal e eram portadores de afecções crônicas não inflamatórias do sistema nervoso. Nos restantes o LCR apresentava alteraçōes de tipos diversos; 4 eram portadores de polirradiculoneurite; um, de meningite crônica; um, de neurolues; 5 , de neurocisticercose.

Os resultados referentes aos pacientes com LCR normal mostraram que há correlação estatìsticamente significativa entre as taxas de SMP no LCR e no sangue. A concentração de SMP no LCR é cêrca da quinta parte da encontrada no sôro.

Entre os pacientes com LCR alterado foi encontrado aumento da relação $\epsilon m$ dois casos de polirradiculoneurite; em ambos havia concentração elevada de SMP no LCR. Nos demais os valôres encontrados para a relação não se afastavam daqueles verificados para pacientes com LCR normal.

\section{SUMMARY}

The diffusion of sulphanilamido-methyl-pirimidine into the cerebrospinal fluid.

The concentration of 2-sulphanilamido-5-methyl-pirimidine (SMP) was studied in the CSF and in the blood of 30 patients with diseases of the nervous system. 
Two groups of patients were considered. The first group was represented by 19 patients in whom the CSF was found to be normal: 10 cases of epilepsy, one case of hydrocephaly, three cases of peripheric neuropathy and five cases of chronic impairment of the spinal cord associated to gastricochloridria. Among the last patients, there was a diminution of the absortion of vitamina $B_{12}$ in two, as it was evidenced by the radiocyanocobalamin absorption test (cases 15 and 19 ).

The second group is represented by 11 patients with changes in the CSF composition: 4 patients with polyradiculoneuritis, one patient with neurosyphilis and 5 patients with cysticercosis of the central nervous system. CSF changes were characterized by the occurrence of protein-cytologic dissociation among the first 4 patients and by pleocitosis of the polynuclear type in the case of meningitis. Complement fixation tests for syphilis in the CSF were positive in the case of neurosyphilis and that for cysticercosis in the CSF of the last 5 cases.

SMP was administered orally to all patients: $1 \mathrm{~g}$ was given initially, and $0.5 \mathrm{~g}$ after 12 and 24 hours. CSF and blood samples were collected 36 hours after the first administration. The concentration of sulfanilamide was determined by the method of Bratton and Marshall with a correction for SMP.

The results are presented in the table 1 . Table 2 shows the mean values obtained in the first group of patients. A positive correlation was found between the concentration of SMP in the blood and in the CSF among the cases of this group. The value of the correlation was statistically significant. The quotient between the concentration of SMP in the CSF and in the blood was represented by $0.203 \pm 0.087$.

The blood concentration of SMP was found to be the lowest in the two cases with deficient absorption of radiocyanocobalamin.

The results obtained for the first group of patients were used as a control for the results obtained for the second group of patients. The results were found to be similar in both groups of patients, with exception of two cases of polyradiculoneuritis. In these the quotient of CSF and blood titer of SMP was found to be increased, due to a relative higher titer in the CSF than in the blood. This is interpreted as due to deficient reabsorption of the CSF, which is admitted to occur in polyradiculoneuritis.

\section{REFERENCIAS}

1. BENZING, H.; DENNIG, H. - Ein Beitrag zu einem neuen Langzeitsulfonamid (Pallidin). Medizinische Welt 1:524-525 (março, 18) 1961. 2. BOGER, W. P. - The diffusion of sulfonamides into the cerebrospinal fluid: a comparative study. Antibiot. Med. a. Clin. Therapy 6:32-40 (janeiro) 1959. 3. BOGER, W. P.; GAVIN, J. J. Sulfamethoxazole: comparison with sulfizoxasole and sulfaethidole and cerebrospinal 
fluid diffusion. Antibiot. a. Chemoter., 10:572-580 (setembro) 1960. 4. BRATTON, A. C.; MARSHALL, E. K. - A new coupling componente for sulfanilamide determination. J. Biol. Chem., 128:537-550, 1939. 5. RENTSCH, M. - Experimentelle Studien mit Sulfadimethoxin (Madribon) in der Paediatrie. Schweiz. Med. Wschr., 90:220-224 (fevereiro, 27) 1960. 6. RUIZ-TORRES, A. - Experimentelle und therapeutische Resultate bei Klinischer Anwendung des 2-Sulfanilamido-5-methylpyrimidin (Pallidin). Medizinische Welt 1:343-346 (fevereiro, 18) 1961. 7. SPINA-FRANCA, A.; SARAIVA, S. - Alterações do proteinograma do liquido cefalorraqueano na polirradiculoneurite. Arq. Neuro-Psiquiat., 19:287-294 (dezembro) 1961.

Clinica Neurológica - Hospital das Clinicas da Fac. Med. da Univ. de São Paulo Caixa Postal 3461 - São Paulo, Brasil. 